\title{
A case of skin lesions of basal cell nevus syndrome
}

\author{
Long Chen ${ }^{1}$, Hui Sun ${ }^{2}$, Meng Zuo ${ }^{2}$, Qing $\mathrm{Xi}^{2}$ \\ ${ }^{1}$ Department of Stomatology, Mancheng District People's Hospital, Baoding City, Hebei Province, China \\ ${ }^{2}$ Stomatology Department, Chinese PLA Hospital, China
}

Adv Dermatol Allergol 2021; XXXVIII (4): 706-707

DOI: https://doi.org/10.5114/ada.2021.108902

Basal cell nevus syndrome (BCNS) is a rare autosomal dominant disorder, and is believed to be caused by mutations in the PTCH gene at locus 9Q22.3-Q31. It is a complex syndrome and consists of multiple odontogenic keratocysts, multiple basal cell nevus (cancer) of the face and neck, punctate depression of the palm and sole, abnormal skeleton and rib, calcification in the brain and various other defects [1, 2]. Now we are reporting a case of BCNS seen in our department recently as follows: female, 20 years old, with typical clinical manifestations of BCNS: multiple and scattered pigmented nevus on the face (Figure $1 \mathrm{~A}$ ), small depression on the palm (Figure 1 B), multiple cysts on the upper and lower jaw, calcification of cerebral falx and tentorium, sternum deformity, rib bifurcations, scoliosis, deviation of the right eye with decreased vision. The mother presented with multiple cysts of the upper and lower jaws, bifurcated ribs, scoliosis and scattered small depressions in the palm (Figure 2).

As early as 1894, Jarisch and White described patients with features typical of the autosomally inherited syn- drome now known as basal cell nevus syndrome (BCNS, also known as Gorlin syndrome). In 1960, Gorlin and Goltz first systematically described the disease [3], believing that the disease is a special disease in its genetic form. The incidence rate is about 1/56000 [4], and the incidence rate of male to female is approximate [5]. At the gene level, the hedgehog signalling pathway is the main signalling pathway involved in the pathogenesis of BCNS $[6,7]$. PTCH1 and G protein couple, together with the secondary receptor smoothed (SMO), regulates the hedgehog signalling pathway, which leads to the growth of basal cell carcinoma [8]. With the deepening of research, PTCH1 is considered as a new diagnostic standard [9], which plays an important role in the pathogenesis of BCNS, especially in patients younger than 20 years old. However, the PTCH1 gene cannot be detected in all patients, and PTCH2 and SUFU genes can be detected in a few patients [9].

BCNS can be accompanied by more than 100 kinds of symptoms and signs, mainly involving the skin, central nervous system, bone system, etc. Basal cell nevus (can-
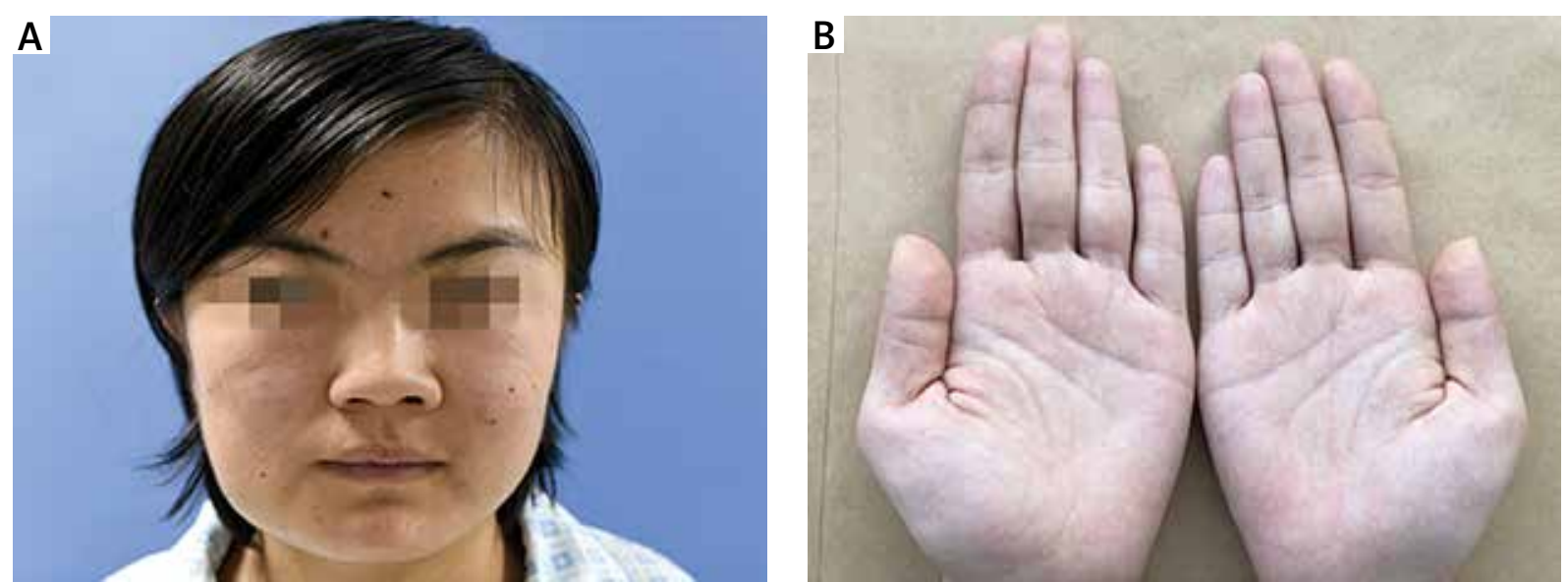

Figure 1. A - Multiple and scattered pigmented nevi on the face of patients. B - Small depressions in the palm of the patient

Address for correspondence: Qing Xi, Stomatology Department, Chinese PLA Hospital, China, e-mail: 41123283@qq.com Received: 13.04 .2020 , accepted: 12.05.2020. 


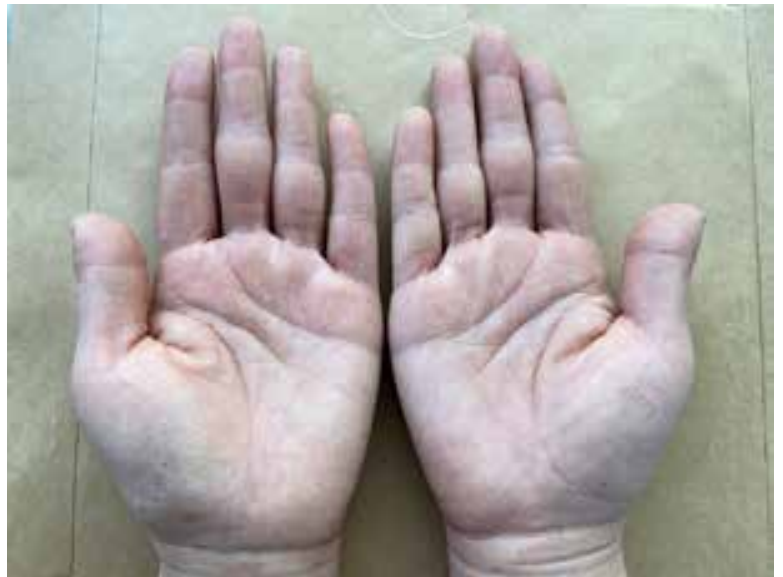

Figure 2. Small depressions in the palm of the mother's hand

cer) is a common clinical manifestation among patients with BCNS, and it cannot be ignored clinically, and can occur in all age groups, especially before the age of 35 . About $10 \%$ of BCNS patients, especially those with dark skin and limited sunlight, have not developed any basal cell cancer; clinically, it is often multiple, occurs in the face and back, but also in other parts of the body [10]. Surgical treatment, microsurgery, photodynamic therapy, laser therapy and local chemotherapy are commonly used in the treatment of basal cell nevus (cancer) [11]. The latest research shows that photodynamic therapy is a good non-cicatricial treatment, and red light (635 m) and blue light $(400 \mathrm{~mm}$ ) have a good therapeutic effect [10]. For a long period of static state of asymptomatic nevus can be regularly followed up, regular follow-up, carried out, and close observation should be carried out to reduce some risky factors. However, if the nevus suddenly increases, any local ulcer, surface crack and other phenomena occur, the chance of canceration is relatively high, and timely treatment should be started, requiring surgical treatment. With the continuous development of new and old technology, there are various treatment methods for basal cell nevus (cancer). In addition to the commonly used treatment methods, we should improve the patients' awareness of prevention, that is, try to reduce the sun exposure, and do a good job of sunscreen (sunscreen, sunglasses, sunscreen clothes) when going out.

\section{Conflict of interest}

The authors declare no conflict of interest.

\section{References}

1. Melo ES, Kawamura JY, Alves CA, et al. Imaging modality correlations of an odontogenic keratocystin the nevoid basal cell carcinoma syndrome: a family case report. Oral Surg Oral Med Oral Pathol Oral Radiol Endod 2004; 98: 232-6.

2. Bakacen G, Rajab LD, Sawair FA, et al. Nevoid basal cell carcinoma syndrome: a review of the literature and a report of a case. Int J Paediatr Dent 2004; 14: 279-87.

3. Gorlin RJ, Goltz RW. Multiple nevoid basal-cell epithelioma, jaw cysts and bifid rib. A syndrome. N Engl J Med 1960; 262: 908-11.

4. Fujii K, Miyashita T. Gorlin syndrome (nevoid basal cell carcinoma syndrome): update and literature review. Pediatr Int 2014; 56: 667-74.

5. Tanioka M, Takahashi K, Kawabata T, et al. Germline mutations of the PTCH gene in Japanese patients with nevoid basal cell carcinoma syndrome. Arch Dermatol Res 2005; 296: 303-8.

6. Athar M, Li CZ, Kim AL, et al. Sonic hedgehog signaling in basal cell nevus syndrome. Cancer Res 2014; 74: 4967-75.

7. Pino LC, Balassiano LK, Sessim M, et al. Basal cell nevus syndrome: clinical and molecular review and case report. Int J Dermatol 2016; 55: 367-75.

8. Kato C, Fujii K, Arai Y, et al. Nevoid basal cell carcinoma syndrome caused by splicing mutations in the PTCH1 gene. Fam Cancer 2017; 6: 131-8.

9. Qu J, Yu F, Hong Y, et al. Underestimated PTCH1 mutation rate in sporadic keracystic odontogenic tumors. Oral Oncol 2015; 51: 40-5.

10. Maytin EV, Kaw U, llyas M, et al. Blue light versus red light for photodynamic therapy of basal cell carcinoma in patients with Gorlin syndrome: a bilaterally controlled comparison study. Photodiagnosis Photodyn Ther 2018; 22: 7-13.

11. Bresler SC, Padwa BL, Granter SR. Nevoid basal cell carcinoma syndrome (Gorlin syndrome). Head Neck Pathol 2016; 10: 119-24. 